\title{
Seroprevalence of feline immunodeficiency virus and feline leukemia virus in domestic cats of Fortaleza, Ceará
}

\section{Soroprevalência do vírus da imunodeficiência felina e do vírus da leucemia felina em gatos domésticos de Fortaleza, Ceará}

\author{
Mariana Araújo Rocha ${ }^{1}$ (D); Reginaldo Pereira Sousa Filho ${ }^{1}$; Keytyanne Oliveira Sampaio ${ }^{2}$; \\ Marina Gabriela Monteiro Carvalho Mori da Cunha ${ }^{3}$ \\ ${ }^{1}$ Universidade Estadual do Ceará, Faculdade de Medicina Veterinária, Fortaleza - CE, Brazil \\ ${ }^{2}$ Universidade Federal Rural de Pernambuco, Recife - PE, Brazil \\ ${ }^{3}$ Katholieke Universiteit Leuven, Leuven - Bélgica
}

\begin{abstract}
Feline Immunodeficiency Virus (FIV) and Feline Leukemia Virus (FeLV) are important etiologic agents of immunosuppressive diseases in felines. The objective of the present study was to determine the prevalence of these retroviruses in domestic cats in Fortaleza, Ceará and the epidemiological factors associated with these infections. Between 2015 and 2016, 138 blood samples were collected and tested for FIV and FeLV by the enzyme immunoadsorption assay (ELISA). Parameters such as breed, gender, age, reproductive status, multi-cat environment, outdoor access and clinical manifestations were evaluated. The results showed that $12.32 \%$ were positive for FIV, 5.80\% for FeLV and 1.45\% for co-infection (FIV/FeLV). $\mathrm{FIV}^{+}$animals were mostly mixed breed, neutered male adult cats, with indoor lifestyle and living in a multi-cat household. The most common clinical manifestation observed was disorders of the oral cavity. Factors found to increase the risk for FeLV seropositivity include mixed breed, young, spayed female cats, indoor lifestyle living in a multi-cat household were the most common epidemiological factors observed. The most common clinical manifestation was anorexia and apathy. The prevalence of these viruses were relatively high, compared with other region of Brazil. This study demonstrated that mixed breed, castrated, multi-cat environment and indoor lifestyle animals are of greater relevance for FIV and FeLV infection diseases. Factors related to cat demographics and health such as age, sex and type of household are important predictors for seropositive status to FeLV or FIV in Fortaleza. High prevalence of FeLV or FIV observed in our study is of concern, in view of the immunosuppressive potential of the two pathogens.
\end{abstract}

Keywords: Felis catus. Infection. Retroviruses. Lentivirus. Epidemiology.

\section{RESUMO}

O Vírus da Imunodeficiência Felina (FIV) e o Vírus da Leucemia Felina (FeLV) são importantes agentes etiológicos de doenças imunossupressoras em felinos. O objetivo do presente estudo foi determinar a prevalência desses retrovírus em gatos domésticos em Fortaleza, Ceará e os fatores epidemiológicos associados a essas infecções. Entre 2015 e 2016, foram coletadas 138 amostras de sangue e testadas para FIV e FeLV pelo ensaio de imunoadsorção enzimática (ELISA). Parâmetros como raça, gênero, idade, estado reprodutivo, ambiente com vários gatos, acesso ao ar livre e manifestações clínicas foram avaliados. Os resultados mostraram que 12,32\% foram positivos para o FIV, 5,80\% para o FeLV e 1,45\% para a co-infecção (FIV/FeLV). Os animais $\mathrm{FIV}^{+}$eram na sua maioria gatos machos castrados, adultos, de raça mista, com estilo de vida dentro de casa e vivendo em um ambiente com vários gatos. A manifestação clínica mais comum observada foi distúrbios da cavidade oral. Os fatores encontrados que aumentam o risco de soropositividade para FeLV incluem gatas fêmeas castradas, jovens, de raça mista, com estilo de vida dentro de casa e vivendo em um ambiente com vários gatos, foram os fatores epidemiológicos mais comuns observados. A manifestação clínica mais comum foi anorexia e apatia. A prevalência desses vírus foi relativamente alta em comparação com outras regiões do Brasil. Este estudo demonstrou que os animais de raça mista, castrados, vivendo em um ambiente com vários gatos e estilo de vida dentro de casa são de maior relevância para as doenças infecciosas por FIV e FeLV. Fatores relacionados à demografia e à saúde do gato, como idade, sexo e tipo de domicílio, são importantes preditores do estado soropositivo para FeLV ou FIV em Fortaleza. A alta prevalência de FeLV ou FIV observada em nosso estudo é preocupante, tendo em vista o potencial imunossupressor dos dois patógenos.

Palavras-chave: Felis catus. Infecção. Retroviruses. Lentivirus. Epidemiologia. 
Correspondence to:

Mariana Araújo Rocha

Universidade Estadual do Ceará, Faculdade de Medicina

Veterinária,

Av. Dr. Silas Munguba, 1700, Campus do Itaperi. CEP: $60714-$

903, Fortaleza - CE, Brazil

e-mail: mariana4981@hotmail.com

Submited: June 03, 2018

Approved: December 18, 2018

How to cite: Rocha MA, Sousa Filho RP, Sampaio KO, Cunha MGMCM. Seroprevalence of feline immunodeficiency viruses and feline leukemia in domestic cats of Fortaleza, Ceará. Braz J Vet Res Anim Sci. 2019;56(1):e146687. https:// doi.org/10.11606/issn.1678-4456.bjvras.2019.146687.

\section{Introduction}

Feline viral immunodeficiency (FIV) and Feline viral leukemia (FeLV) are retrovirus diseases. FIV is a lentivirus that leads to a progressive immune system dysfunction resulting in a greater susceptibility to opportunistic infections and degenerative diseases (Sellon \& Hartmann, 2012). Felines affected by FIV may present apathy, lymphadenomegaly, hepatosplenomegaly, lymphoplasmacytic gingivitis-stomatitis complex (LGSC), weight loss, dermatitis, neoplasias, glomerulo-nephritis and respiratory tract diseases, which are often secondary infections (Hosie et al., 2009; Sobrinho et al., 2011). The transmission by FIV occurs mainly through the saliva, where the virus is inoculated by bites (Ravi et al., 2010).

Feline leukemia virus (FeLV) is an oncogenic and immunosuppressive gammaretrovirus, mainly transmitted by the oronasal pathway (Levy et al., 2008; Lutz et al., 2009). Comorbidities in FeLV-infected cats include lymphoma, leukemia, mycoplasmosis, hemolytic anemia, lymphadenopathy, LGSC, chronic rhinitis, and polyarthritis (Coelho et al., 2011; Lutz et al., 2009).

The diagnosis should be based on clinical examination and laboratory tests. The most widely used methods for detecting these viruses are the enzyme-linked immunosorbent assay (ELISA), immunochromatography and western blot, which detect antibodies or specific antigens, and the polymerase chain reaction (PCR), which detects proviral DNA (Hosie et al., 2009; Lutz et al., 2009).

The seroprevalence of FIV and FeLV varies greatly, depending on the age, gender and health status of the animals (Little et al., 2009). The percentage of infected for FIV ranges from $3.2 \%$ to $15 \%$ and FeLV from $1 \%$ to $4 \%$ in populations of cats from various parts of the world
(Gleich et al., 2009; Little et al., 2009; Westman et al., 2016). In some counties of Brazil, such as Belo Horizonte - MG, Rio Grande - RS, São Paulo - SP and Pelotas - RS, with prevalence ranging from $4.1 \%$ to $15.7 \%$ and from $6.2 \%$ to $38.3 \%$ of animals positive for FIV and FeLV have been reported, respectively, using serological techniques (direct and indirect immunofluorescence), PCR, or by nested PCR (Jorge et al., 2011; Lara et al., 2008; Meinerz et al., 2010; Silva et al., 2014; Teixeira et al., 2007).

The depletion of the immune system is the main cause of the high morbidity and mortality of the seropositive felines for the retroviruses. Epidemiological research of FIV and FeLV are of great importance for implementing disease control and prevention measures, since these viruses lead to nonspecific clinical signs and are highly contagious.

The objective of this study was to conduct an epidemiological survey and to evaluate the occurrence of FIV and FeLV infections in domestic cats treated in different regions of Fortaleza, through the technique of detection of antibodies and antigens by ELISA.

\section{Material and methods}

\section{Study area}

The research was carried out in a survey and analysis of 138 clinical records of domestic cats from the North, South, East and West regions of Fortaleza, Ceará, from 2015 to 2016, treated at a private veterinary clinic.

\section{Samples}

Blood samples were collected through venipuncture of saphenous or jugular to perform a viral screening by ELISA test (SNAP FIV / FeLV Combo test, IDEXX System), which detects FeLV p27 antigen and antibodies specific for FIV, since this test has high accuracy, readiness and ease.

\section{Risk factors}

Possible risk and protective factors associate with FIV and FeLV infection were evaluated using the clinical records of all positive cats. Data such as breed, gender, age group, reproductive status, multi-cat environment, outdoor access and clinical manifestations were recorded and analyzed. The age group was divided according to the animal life stage, such as junior (6 months to 1 year), prime ( 1 to 5 years), mature (6 to 10 years), and senior to geriatric (from 11 years). The multi-cat environment was analyzed from the presence of one or more cats in the same household. Access to the outside was analyzed through one or more exits of the animal from inside the 
house. Prevalence was determined as number of cats with a positive serological test divided by the total number of cats evaluated.

\section{Results}

The sample of the 138 felines consisted of: 75 females and 63 males, of which 114 were mixed breed (MB), 19 Persians, 2 Exotics, 1 Maine Coon, 1 Angora and 1 American Shorthair, ranging from 6 months to 18 years. Of the 138 animals tested, 17 (12.32\%) tested positive for FIV, 8 (5.80\%) for FeLV, and 2 (1.45\%) for both retroviruses (FIV/FeLV).

The descriptive characteristics of seropositive felines are displayed in Table 1. Regarding the racial distribution, there was a higher occurrence in mixed breed animals for FIV, FeLV and FIV/FeLV and the presence of positivity was observed only in the Persian breed. According to the sex, males obtained a higher prevalence of positivity for FIV and FIV/FeLV; however, in the case of FeLV, there was a higher occurrence of females in relation to males (Table 1).
The highest number of cats positive for FIV and FIV/FeLV were mature-adults, while for FeLV, they were prime-adult castrated animals with indoor lifestyle, which had multi-cat environment with other cats and a higher frequency in both retroviruses and in their association.

All seropositive cats had some clinical manifestation (Table 2). Among the animals infected with FIV, the most common clinical signs observed were higher periodontal diseases and ophthalmological-auricular-nasal disorders. Other clinical signs observed were weight loss and bilateral submandibular lymph node hypertrophy, as well as anorexia, apathy, diarrhea, dysphagia, emesis and hyperthermia.

$\mathrm{FeLV}^{+}$felines presented anorexia and apathy more frequently, and other comorbidities such as ophthalmological, auricular, nasal cavity disorders, anemia, splenomegaly and nephromegaly, neurological disorders and bilateral submandibular lymphadenomegaly were also observed. The co-infected animals presented neurological signs, apathy, periodontal diseases and bilateral submandibular lymph node hypertrophy (Table 2).

Table 1 - Descriptive characteristics of the feline immunodeficiency virus (FIV) and feline leukemia virus (FeLV) seropositive cat population in Fortaleza-CE

\begin{tabular}{|c|c|c|c|c|}
\hline & & FIV $(n=17)$ & FeLV $(n=8)$ & FIV/FeLV $(n=2)$ \\
\hline \multirow[t]{2}{*}{ Breed } & Mixed breed & $16(94,12 \%)$ & 7 (87,50\%) & $2(100 \%)$ \\
\hline & Persian & $1(5,88 \%)$ & $1(12,50 \%)$ & $0(0 \%)$ \\
\hline \multirow[t]{2}{*}{ Gender } & Male & $10(58,82 \%)$ & $3(37,50 \%)$ & $2(100 \%)$ \\
\hline & Female & $7(41,18 \%)$ & $5(62,50 \%)$ & $0(0 \%)$ \\
\hline \multirow[t]{4}{*}{ Age range } & 6 months to 1 year & $1(5,88 \%)$ & $1(12,50 \%)$ & $0(0 \%)$ \\
\hline & $1-5$ years & $6(35,29 \%)$ & $5(62,50 \%)$ & $0(0 \%)$ \\
\hline & $6-10$ years & $7(41,18 \%)$ & $2(25,00 \%)$ & $2(100 \%)$ \\
\hline & $>11$ years & $3(17,65 \%)$ & $0(0 \%)$ & $0(0 \%)$ \\
\hline \multirow[t]{2}{*}{ Reproductive state } & Castrated & $12(70,59 \%)$ & $7(87,50 \%)$ & $2(100 \%)$ \\
\hline & Intact & $5(29,41 \%)$ & $1(12,50 \%)$ & $0(0 \%)$ \\
\hline \multirow[t]{2}{*}{ Household type } & Multi-cat & $15(88,24 \%)$ & $7(87,50 \%)$ & $2(100 \%)$ \\
\hline & Single & $2(11,76 \%)$ & $1(12,50 \%)$ & $0(0 \%)$ \\
\hline \multirow[t]{2}{*}{ Outdoor access } & Yes & $7(41,18 \%)$ & $1(12,50 \%)$ & $1(50,00 \%)$ \\
\hline & No & $10(58,82 \%)$ & $7(87,50 \%)$ & $1(50,00 \%)$ \\
\hline
\end{tabular}

Table 2 - Number of seropositive felines for FIV and/or FeLV, and clinical manifestations

\begin{tabular}{|c|c|c|c|}
\hline Clinical signs & FIV $(n=17)$ & FeLV $(n=8)$ & FIV/FeLV $(n=2)$ \\
\hline Anemia & $0(0 \%)$ & $2(25,00 \%)$ & $0(0 \%)$ \\
\hline Anorexia & $4(23,53 \%)$ & $4(50,00 \%)$ & $0(0 \%)$ \\
\hline Apathy & $3(17,65 \%)$ & $4(50,00 \%)$ & $1(50,00 \%)$ \\
\hline Diarrhea & $3(17,65 \%)$ & $0(0 \%)$ & $0(0 \%)$ \\
\hline Dysphagia & $3(17,65 \%)$ & $0(0 \%)$ & $0(0 \%)$ \\
\hline Neurological disorders & $0(0 \%)$ & $2(25,00 \%)$ & $1(50,00 \%)$ \\
\hline Ophthalmologic / auricular / nasal disorders & $9(52,94 \%)$ & $3(37,50 \%)$ & $0(0 \%)$ \\
\hline Weight loss & $6(35,29 \%)$ & $0(0 \%)$ & $0(0 \%)$ \\
\hline Emesis & $2(25,00 \%)$ & $0(0 \%)$ & $0(0 \%)$ \\
\hline Splenomegaly / Nephromegaly & $0(0 \%)$ & $2(25,00 \%)$ & $0(0 \%)$ \\
\hline Periodontal diseases & $11(64,70 \%)$ & $0(0 \%)$ & $1(50,00 \%)$ \\
\hline Hyperthermia & $2(11,76 \%)$ & $0(0 \%)$ & $0(0 \%)$ \\
\hline Bilateral submandibular lymphadenomegaly & $6(35,29 \%)$ & $2(25,00 \%)$ & $1(50,00 \%)$ \\
\hline
\end{tabular}




\section{Discussion}

The prevalence of $12.32 \%$ for FIV and 5.80\% for FeLV in Fortaleza-CE varied from the results found, through serological methods, in other cities of Brazil: $0.78 \%$ and 0.36\% in São Paulo (Santos et al., 2013), 5.63\% and 0.33\% in Araçatuba-SP (Sobrinho et al., 2011) for FIV and FeLV, respectively, and 38.3\% in Pelotas and Rio Grande-RS for FeLV (Meinerz et al., 2010). Felines with FIV and FeLV detected by PCR or nested PCR were $4.14 \%$ and $47.0 \%$ in Belo Horizonte (Teixeira et al., 2007; Coelho et al., 2011), respectively, and $15.70 \%$ for FIV in Pelotas - RS (Silva et al., 2014), and there was no presence of co-infection of these diseases in these studies. The discrepancy between the values found by the authors may reflect the methods used, since serological techniques show high specificity and sensitivity, with false negative results in cats regressively infected with FeLV and false positives for FIV due to the presence of maternal antibodies, especially in cats younger than six month-old (Hosie et al., 2009; Little et al., 2011). However, we cannot discard in the present study the possibility of actually having a higher proportion of $\mathrm{FIV}^{+}$patients.

The presence of FIV, FeLV and FIV / FeLV positivity was found to be similar to that of a veterinary hospital in Australia, which, through immunochromatography, presented values of $14.00 \%, 4.00 \%$ and $2.00 \%$ (Westman et al., 2016) for the respective viruses. The prevalence of FIV, FeLV and FIV / FeLV in this study is higher than in Germany and western Canada (Gleich et al., 2009; Ravi et al., 2010) (4.14). The observed differences can be attributed due to the population density of cats, lifestyles, variation between geographic regions and control policies (Bande et al., 2012). The absence of effective vaccination for FIV and the scarce routine vaccination for FeLV in Brazil may be associated with the high occurrence of feline retroviruses observed in this study in relation to other countries. We would like to note that all animals in this study were not vaccinated for FeLV.

As to racial predisposition, a higher prevalence of mixed breed animals was observed, corroborating with other studies (Sobrinho et al., 2011; Santos et al., 2013), and these values can be attributed to the higher occurrence of these animals in the clinical routine.

There was a higher incidence of FIV positivity among males, reinforcing the study by Chhetri et al. (2015) and Lara et al. (2008), indicating that territorial disputes, fights and mating may predispose bites, which is the main mode of transmission of this virus (Levy et al., 2008; Hosie et al., 2009). In the case of cats with FeLV, a higher occurrence was observed in females, similarly to that identified by
Santos et al. (2013), which can be attributed to the more docile and prolonged behavior among these animals (Hartmann, 2012); however, Gleich et al. (2009) showed that cats exhibiting aggressive behavior may have a higher risk of FeLV infection.

The rates of FIV and FeLV positivity are related to age and increased immune response (Levy et al., 2006). The highest number of $\mathrm{FIV}^{+}$animals was in the age range of 6 to 10 years, as observed in previous studies (Ravi et al., 2010). This assertion reinforces the hypothesis that this disease is usually diagnosed in adult cats, since the asymptomatic period lasts for years (Hosie et al., 2009). Among FeLV+ animals, a greater prevalence was observed between 1 and 5 years of age, similar to the one found in the city of São Paulo, which observed a significant number of positive animals between 3 and 6 years of age (Jorge et al., 2011). This high proportion of $\mathrm{FeV}^{+}$felines in young adults and the absence of seropositive individuals above 11 years of age may be justified by the high mortality rate in infected young animals, as well as being more susceptible, while older cats are more resistant (Coelho et al., 2011; Hartmann, 2012). However, Westman et al. (2016) demonstrated that older cats are as susceptible to infection as young ones. Some older cats living in confinement may be positive for FeLV due to reactivation of the virus that remained in the latency state (Hartmann, 2012).

Castration is a method that mainly reduces the vertical transmission mode (Levy et al., 2008). Most animals positive for FIV and FeLV were castrated (Jorge et al., 2011; Silva et al., 2014), contrary to a study carried out in 10 provinces of Canada (Little et al., 2009). Many of the clinic visits are from castrated animals, and many of these have not been tested prior to the surgical procedure and thus could be positive prior to castration.

FIV and FeLV are common diseases in cats that keep contact and live in a group. The multi-cat environment had a high frequency in both retroviruses, demonstrating that frequent contact between infected cats is a high risk factor for transmission of these agents. Bande et al. (2012) conducted a study in clinics and shelters in Malaysia, and showed that cats living in multi-cat environments are more likely to be $\mathrm{FeLV}^{+}$, in agreement with the present study. Overcrowding of cats in homes can result in stress, poor hygiene and closer contact between these animals (Bande et al., 2012), thus facilitating the propagation of FeLV, since activities such as licking and sharing bowls of food and water are the main means of the transmission (Hartmann, 2012). Felines residing in locations with other cats should be tested for FIV and FeLV in addition to being vaccinated against FeLV to prevent the spread of these diseases. 
Animals with outdoor access are more predisposed to get contaminated. However, most $\mathrm{FIV}^{+}$and $\mathrm{FeLV}^{+}$cats in our study did not have outdoor access, suggesting that the virus infection occurred before the period of adoption and subsequent confinement, besides the possibility of transmission by its contactors. Studies from Gleich et al. (2009) and Little et al. (2009) have shown that cats with outdoor access are the most predisposed to contamination. Isolating a cat with retrovirus is an important measure to prevent secondary infections, since in addition to these infections causing clinical signs, they also may increase the progression of FIV and FeLV (Hosie et al., 2009; Lutz et al., 2009).

A wide variety of diseases were present in cats infected with FIV, FeLV and FIV / FeLV. Clinical findings are usually due to immunodeficiency or uncontrolled immune stimulation. In the present study, the clinical manifestation of LGSC was the most frequent in FIV-positive cats (Ravi et al., 2010; Santos et al., 2013), suggesting that the immunosuppressive effect of FIV allows the entry of infectious agents into the oral cavity. Ophthalmologic, auricular, nasal cavity, weight loss and lymphadenomegaly disorders have been reported to be significant, since the latter two are reported in cats with FIV. In the initial phase of FIV infection, there is a limited number of signs, making an early diagnosis difficult. So, it is extremely important to perform tests for FIV and FeLV in the routine of feline patients.

The most frequent clinical manifestations in animals with FeLV were anorexia and apathy, diverging from other studies in Brazil (Coelho et al., 2011; Santos et al., 2013), which presented lymphoma and lymphadenopathy as the main clinical findings. Lymphoma and leukemia are the most frequent diseases in animals with FeLV (Lutz et al., 2009), but were not observed in this study. Anemia was observed in two seropositive animals for FeLV, and may be related to secondary infections, autoimmune anemias or spinal cord hypoplasia, due to the effect of the virus infection (Lutz et al., 2009). According to Pedersen et al. (1990), animals co-infected with FIV and FeLV have a severe influence on the progression of the disease, and may be caused by the interaction of both viruses in the patient's immune system, which was also observed in this study.

\section{Conclusions}

This study demonstrated that mixed breed, castrated, multi-cat environment and indoor lifestyle animals are of greater relevance for FIV and FeLV infection diseases. High prevalence of FeLV or FIV observed in our study is of concern, in view of the immunosuppressive potential of the two pathogens. This reaffirms the importance of testing all the cats that are taken care of in Fortaleza. This strategy will provide a better quality of life for these animals, since an earlier diagnosis can be done. New strategies for control and prevention, such as screening and routine vaccination, should be implemented in order to ensure that FeLV and FIV are controlled in the cat population of Fortaleza.

\section{Conflicts of Interest}

They affirm that they do not have any conflict of interest with the topic addressed in the article, nor with the products / items cited. We declare that the article quoted above is original and that the work, in part or in full, or any other work with substantially similar content, has not been submitted to another scientific journal and will not be, while its publication is being considered by the Brazilian Journal of Veterinary Research and Animal Science, whether in print or electronic form. The authors below declare that they participated in the conception, analysis of results and contributed effectively to the accomplishment of the article: Seroprevalence of feline immunodeficiency viruses and feline leukemia in domestic cats of Fortaleza, Ceará. They assume public responsibility for its content, that no links or financing agreements between authors and companies that may be interested in the publication of this article were omitted.

\section{Ethics Statement}

We testify that our article "Seroprevalence of feline immunodeficiency viruses and feline leukemia in domestic cats of Fortaleza, Ceará" was submitted to the Brazilian Journal of Veterinary Research and Animal Science and this material has not been published in whole or in part elsewhere. The manuscript is not being considered for publication in another journal. All authors have been personally and actively involved in the manuscript, and are jointly and individually responsible for their content.

\section{References}

Bande F, Arshad SS, Hassan L, Zakaria Z, Sapian NA, Rahman NA, Alazawy A. Prevalence and risk factors of feline leukaemia virus and feline immunodeficiency virus in peninsular Malaysia. BMC Vet Res. 2012;8(33):33-6. http://dx.doi.org/10.1186/17466148-8-33 PMid:22439903. 
Chhetri BK, Berke O, Pearl DL, Bienzle D. Comparison of risk factors for seropositivy to feline immunodeficiency virus and feline leukemia virus among cats: a case-case study. BMC Vet Res. 2015;11(30):1-7. https://doi.org/10.1186/ s12917-015-0339-3 PMid: 25889006.

Coelho FM, Maia MQ, Luppi MM, Costa EA, Luiz APMF, Ribeiro NA, Bomfim MRQ, Fonseca FG, Resende M. Ocorrência do vírus da leucemia felina em Felis cattus em Belo Horizonte. Arq Bras Med Vet Zootec. 2011;63(3):77883. http://dx.doi.org/10.1590/S0102-09352011000300037.

Gleich SE, Krieger S, Hartmann K. Prevalence of feline immunodeficiency virus and feline leukaemia virus among client-owned cats and risk factors for infection in Germany. J Feline Med Surg. 2009;11(12):985-92. http:// dx.doi.org/10.1016/j.jfms.2009.05.019 PMid:19616984.

Hartmann K. Feline leukemia virus infection. In: Greene $\mathrm{CE}$, editor. Infectious diseases of the dog and cat. 4th ed. Missouri: Saunders; 2012. p. 108-35.

Hosie MJ, Addie D, Belák S, Boucraut-Baralon C, Egberink H, Frymus T, Gruffydd-Jones T, Hartmann K, Lloret A, Lutz H, Marsilio F, Pennisi MG, Radford AD, Thiry E, Truyen U, Horzinek MC. Feline immunodeficiency: $\mathrm{ABCD}$ guidelines on prevention and management. J Feline Med Surg. 2009;11(7):575-84. http://dx.doi.org/10.1016/j. jfms.2009.05.006 PMid:19481037.

Jorge JJ, Ferreira F, Hagiwara MK. Risk factors for feline leucemia virus (FeLV) infection in cats in São Paulo, Brasil. Braz J Vet Res Anim Sci. 2011;48(5):392-8. http://dx.doi. org/10.11606/S1413-95962011000500006.

Lara VM, Taniwaki AS, Araújo JPA Jr. Occurrence of feline immunodeficiency virus infection in cats. Cienc Rural. 2008;38(8):2245-9. http://dx.doi.org/10.1590/S010384782008000800024 .

Levy J, Crawford C, Hartmann K, Hofmann-Lehmann R, Little S, Sundahl E, Thayer V. 2008 American association of feline practitioners' feline retrovirus management guidelines. J Feline Med Surg. 2008;10(3):300-16. http:// dx.doi.org/10.1016/j.jfms.2008.03.002 PMid:18455463.

Levy JK, Scott HM, Lachtara JL, Crawford PC, Edinboro $\mathrm{CH}$, Glotfelty CS, Dingman PA, West AL, Cady-Kirkland KD. Seroprevalence of feline leukemia virus and feline immunodeficiency virus infection among cats in North America and risk factors for seropositivity. J Am Vet Med Assoc. 2006;228(3):371-6. http://dx.doi.org/10.2460/ javma.228.3.371 PMid:16448357.
Little S, Bienzle D, Carioto L, Chisholm H, O'Brien E, Scherk M. Feline leukemia virus and feline immunodeficiency virus in Canada: recommendations for testing and management. Can Vet J. 2011;52(8):849-55. PMid:22294790.

Little S, Sears W, Lachtara J, Bienzle D. Seroprevalence of feline leukemia virus and feline immunodeficiency virus infection among cats in Canada. Can Vet J. 2009;50(6):6448. PMid:19721785.

Lutz H, Addie D, Belák S, Boucraut-Baralon C, Egberink H, Frymus T, Gruffydd-Jones T, Hartmann K, Hosie MJ, Lloret A, Marsilio F, Pennisi MG, Radford AD, Thiry E, Truyen U, Horzinek MC. Feline leukaemia: ABCD guidelines on prevention and management. J Feline Med Surg. 2009;11(7):565-74. http://dx.doi.org/10.1016/j. jfms.2009.05.005 PMid:19481036.

Meinerz ARM, Antunes TA, Souza LL, Nascente PS, Faria RO, Cleff MB, Gomes FR, Nobre MO, Reischak D, Schuch LFD, Meireles MCA. Frequência do vírus da leucemia felina (VLFe) em felinos domésticos (Felis catus) semidomiciliados nos municípios de Pelotas e Rio Grande. Cienc Anim Bras. 2010;11(1):90-3. https://doi.org/10.5216/cab.v11i1.438.

Pedersen NC, Torten M, Rideout B, Sparger E, Tonachini T, Luciw PA, Ackley C, Levy N, Yamamoto J. Feline leukemia virus infection as a potentiating cofactor for the primary and secondary stages of experimentally induced feline immunodeficiency virus infection. J Virol. 1990;64(2):598606. PMid:2153226.

Ravi M, Wobeser GA, Taylor SM, Jackson ML. Naturally acquired feline immunodeficiency virus (FIV) infection in cats from western Canada: Prevalence, disease associations, and survival analysis. Can Vet J. 2010;51(3):271-6. PMid:20514250.

Santos DL, Lucas R, Lallo MA. Epidemiologia da imunodeficiência viral, leucemia viral e peritonite infecciosa em felinos procedentes de um hospital veterinário. Rev Acad Ciênc Agrár Ambient. 2013;11(2):161-8. http://dx.doi. org/10.7213/academica.011.002.AO06.

Sellon RK, Hartmann K. Feline immunodeficiency virus infection. In: Greene CE, editor. Infectious diseases of the dog and cat. 4th ed. Missouri: Saunders; 2012. p. 136-48.

Silva FS, Castro CC, Finger PF, Silva DS, Taniwaki SA, Ullmann LS, Fischer G, Vargas GD, Lima M, Araújo JP Jr, Hübner SO. Ocorrência do subtipo B do vírus da imunodeficiência felina em gatos domésticos da região sul do estado do Rio Grande do Sul, Brasil. Arq Bras Med Vet 
Zootec. 2014;66(1):1-6. http://dx.doi.org/10.1590/S010209352014000100001.

Sobrinho LSV, Vides JP, Braga ET, Gomes AAD, Rossi $\mathrm{CN}$, Marcondes M. Sorofrequência de infecção pelo vírus da imunodeficiência felina e vírus da leucemia felina em gatos do município de Araçatuba, São Paulo. Braz J Vet Res Anim Sci. 2011;48(5):378-83. http://dx.doi.org/10.11606/ S1413-95962011000500004

Teixeira BM, Rajao DS, Haddad JPA, Leite RC, Reis JKP. Ocorrência do vírus da imunodeficiência felina e do vírus da leucemia felina em gatos domésticos mantidos em abrigos no município de Belo Horizonte. Arq Bras Med Vet Zootec. 2007;59(4):939-42. http://dx.doi.org/10.1590/ S0102-09352007000400019.

Westman ME, Paul A, Malik R, Mcdonagh P, Ward MP, Hall E, Norris JM. Seroprevalence of feline immunodeficiency virus and feline leukaemia virus in Australia: risk factors for infection and geographical influences (2011-2013). J Feline Med Surg Open Rep. 2016;2(1):1-11. http://dx.doi. org/10.1177/2055116916646388.

Financial Support: Author declares this study has been exempt of financial support.

Authors Contributions: Mariana Araujo Rocha was responsible for the project, participated in all planning, execution and preparation of the manuscript. Reginaldo Pereira de Sousa Filho participated in the planning, execution and confection of the manuscript. Keytyanne de Oliveira Sampaio participated in the planning, execution and confection of the manuscript. Marina Gabriela Monteiro Carvalho Mori Cunha was advisor and supervisor of the project. 